${ }^{\bullet}$ Entomologica Fennica. 5 December 1995

\title{
Immigration and range expansion in Finnish insects
}

\author{
Hans Silfverberg
}

Silfverberg, H. 1995: Immigration and range expansion in Finnish insects. Entomol. Fennica 6:163-167.

During the 20th century many insect species have expanded into Finland and established themselves as part of the fauna. Some species of Coleoptera seem to have been carried here originally by man, but nowadays live outdoors. Many other species seem to have reached Finland on their own, and colonized a minor or major part of the country. Most colonists have come from the south, only a few from the east or north-east. This article lists various kinds of newcomers to Finland.

Hans Silfverberg, Naturhistoriska Centralmuseet, Entomologiska avdelningen, Box 17, FIN-00014 Helsingfors Universitet, Finland

The Finnish insect fauna has been studied for more than two hundred years, and by now we can recognize several changes. Some species have disappeared from Finland; a list prepared for the Ministry of Environment (Rassi 1992) includes 59 such species, 39 of them in Coleoptera, 10 in Lepidoptera. On the other hand, an average of almost one hundred new insect species have been reported each year (Silfverberg 1991). Of course, rather few of these species are truly new, most have merely not been recognized before. In addition there is a considerable number of species introduced by man, some of them with no chance to survive in Finland, others entirely dependent on greenhouses or similar artificial environments.

There is also a small number of insects that have unintentionally been introduced into Finland by man, but which have managed to establish themselves outdoors, some still limited to human environments (e.g. compost heaps or garbage dumps), but others nowadays even living deep in the forests. A number of such beetles are listed in Table 1. Many of these species were originally described from East Asia, and some have spread very widely; for instance Atomaria lewisi is established in Iceland (Ólafsson 1991), and it has even been recorded from Spitzbergen (Kangas 1967).

Table 1. Exotic colonists that have established themselves outdoors in Finland, with year of first record. Species marked with * have been reported from old forest areas in Finland (Rutanen 1994, Muona pers. comm.).

\begin{tabular}{ll}
\hline Perigona nigriceps (Dejean) & 1961 \\
Cercyon laminatus Sharp & 1960 \\
Cryptopleurum subtile Sharp & 1957 \\
Baeocrara japonica (Matthews) & 1974 * \\
Acrotrichis insularis (Mäklin) & 1981 * \\
Philonthus rectangulus Sharp & 1936 \\
Philonthus spinipes Sharp & 1991 \\
Philonthus parcus Sharp & 1964 \\
Lithocharis nigriceps Kraatz & 1940 \\
Oxytelus migrator Fauvel & 1975 \\
Acrotona pseudotenera (Cameron) & 1988 \\
Carpophilus marginellus Motschulsky & 1982 * \\
Atomaria lewisi Reitter & 1959 * \\
Aridius nodifer (Westwood) & 1924 *
\end{tabular}


Table 2. Expanding insect species in Finland, with year of first observation and direction of arrival. References: B84 = Biström 1984, BV85 = Biström \& Väisänen 1985, C91 = Clayhills 1991, H68 = Hackman 1968, H83 = Hackman \& al. 1983, H90 = Holmberg 1990, J91 = Jansson 1991, J92 = Jalas 1992, K62 = Kaisila 1962, K75 = Koponen $1975 \& 1980, K 86=$ Koponen \& Ilvessalo 1986, L50 = Lindberg 1950, L72 = Lindroth 1972, M77 = Mikkola \& Jalas 1977, M89 = Mikkola \& al. 1989, M90 = Marttila \& al. 1990, N69 = Nordström \& al. 1969, P81 = Pekkarinen \& al. 1981, R90 = Repo 1990, R92 = Rutanen 1992, R94 = Repo 1994, S23 $=$ Saalas 1923, S90 = Silfverberg 1990, V46 = Valle 1946, V64 = Viramo 1964.

\begin{tabular}{|c|c|c|c|}
\hline $\begin{array}{l}\text { Odonata } \\
\text { Libellula depressa Linnaeus }\end{array}$ & 1919 & SE & V46 \\
\hline \multicolumn{4}{|l|}{ Heteroptera } \\
\hline Acanthosoma haemorrhoidale (Linnaeus) & 1921 & SW & L50 \\
\hline Troilus luridus (Fabricius) & 1935 & SW & L50 \\
\hline Palomena prasina (Linnaeus) & 1939 & SW & L50 \\
\hline \multicolumn{4}{|l|}{ Coleoptera } \\
\hline Amara majuscula (Chaudoir) & 1930 & $\mathrm{~s}$ & L72 \\
\hline Amara hyperborea Dejean & 1927 & NE & B84 \\
\hline Stenolophus mixtus (Herbst) & 1935 & $\mathrm{~s}$ & L72 \\
\hline Gabrius astutoides (Strand) & 1979 & SW & C91 \\
\hline Acrotona parens (Mulsant \& Rey) & 1983 & s & R92 \\
\hline Oryctes nasicornis (Linnaeus) & 1920 & S & V64 \\
\hline Cantharis lateralis Linnaeus & 1942 & SE & S90 \\
\hline Ctenicera cuprea (Fabricius) & 1899 & NE & S23 \\
\hline Hippodamia notata (Laicharting) & 1973 & $\mathrm{E}$ & $\mathrm{H} 90$ \\
\hline Metoecus paradoxus (Linnaeus) & 1948 & $\mathrm{~s}$ & K86 \\
\hline Agapanthia villosoviridescens (Degeer) & 1979 & SE & BV85 \\
\hline Gronops inaequalis Boheman & 1941 & SE & S90 \\
\hline Ips amitinus (Eichhoff) & 1950 & $\mathrm{~S}$ & K75 \\
\hline \multicolumn{4}{|l|}{ Lepidoptera } \\
\hline Epiblema grandaevana (Lienig \& Zeller) & 1956 & SE & J92 \\
\hline Catoptria fulgidella (Hübner) & 1957 & $\mathrm{~S}$ & J92 \\
\hline Araschnia levana (Linnaeus) & 1973 & $\mathrm{E}$ & M90 \\
\hline Discoloxia blomeri (Curtis) & 1966 & $\mathrm{~S}$ & M89 \\
\hline Ourapteryx sambucaria (Linnaeus) & 1961 & SE & M89 \\
\hline Hypomecis roboraria (Denis \& Schiffermüller) & 1952 & SE & M89 \\
\hline Macdunnoughia confusa (Stephens) & 1936 & $S$ & K62 \\
\hline Apamea scolopacina (Esper) & 1966 & S & R90 \\
\hline Luperina testacea (Denis \& Schiffermüller) & 1942 & SW & N69 \\
\hline Staurophora celsia (Linnaeus) & 1934 & SW & K62 \\
\hline Archanara sparganii (Esper) & 1937 & $\mathrm{~s}$ & K62 \\
\hline Orthosia munda (Denis \& Schiffermüller) & 1990 & SW & R94 \\
\hline Cryptocala chardinyi (Boisduval) & 1957 & SE & M77 \\
\hline Xestia sexstrigata (Haworth) & 1932 & SW & K62 \\
\hline \multicolumn{4}{|l|}{ Diptera } \\
\hline Rhamphomyia marginata (Fabricius) & 1967 & S & H68 \\
\hline Urophora cardui (Linnaeus) & 1981 & $\mathrm{~s}$ & J91 \\
\hline Lipoptena cervi (Linnaeus) & 1960 & SE & $\mathrm{H} 83$ \\
\hline \multicolumn{4}{|l|}{ Hymenoptera } \\
\hline Bombus sylvarum (Linnaeus) & 1944 & SE & P81 \\
\hline
\end{tabular}




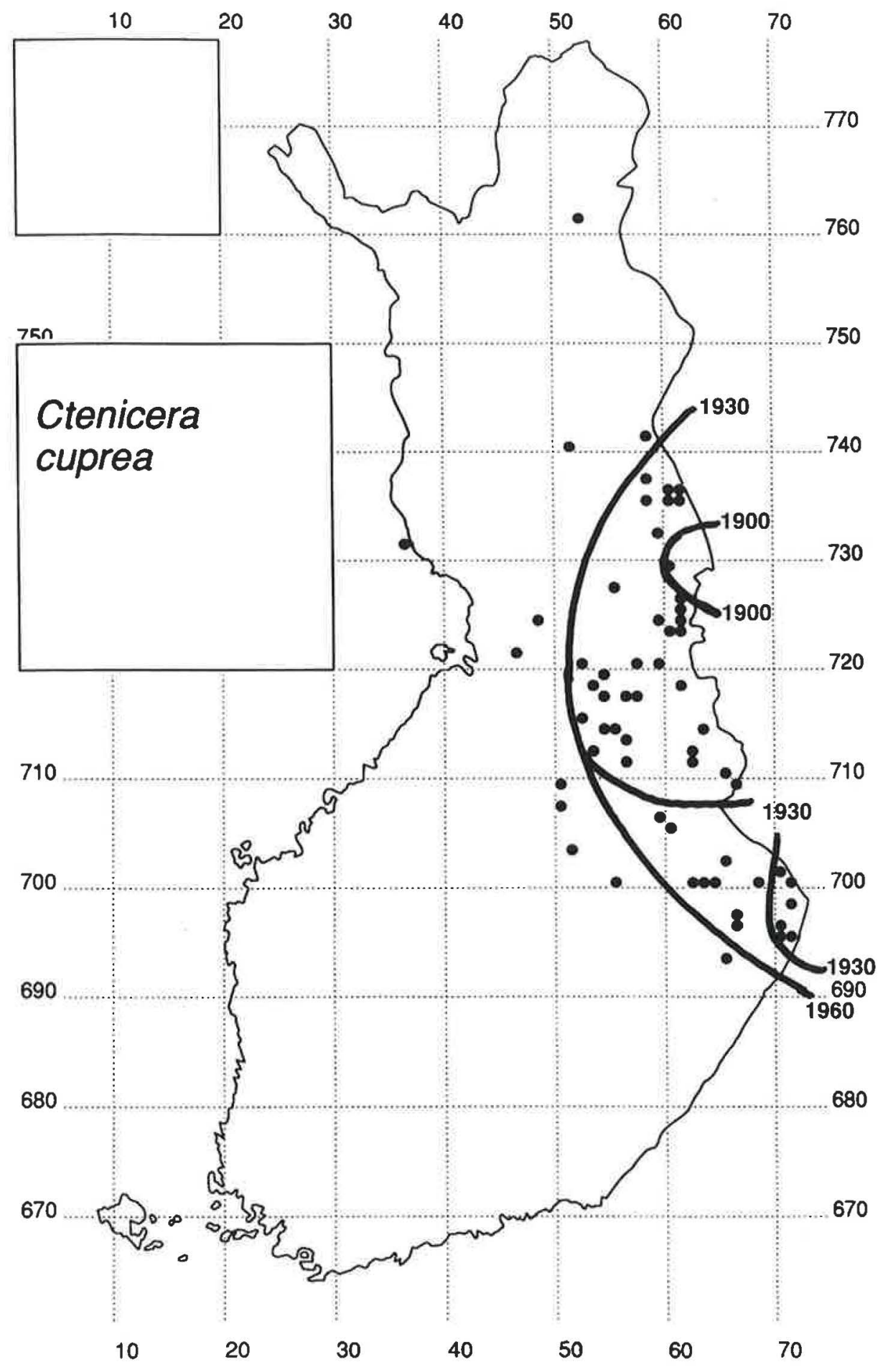

Fig. 1. The present distribution of Ctenicera cuprea in Finland, and the limits reached by 1900, 1930 and 1960. 
Yet there are cases where we have sufficient information to conclude that a spontaneous range expansion has occurred.

The best observations have been made on Lepidoptera; the numerous amateur lepidopterists have proven to be an invaluable asset for scientists analyzing the dispersal. Kaisila (1962) studied the records for a large number of Lepidopteran species, and could present a picture of how they have spread, and occasionally again retreated. In Table 2 a few of these species are listed, and also some later arrivals.

In other orders documentation is generally poorer, and detailed information on dispersal can mainly be found for conspicuous or economically important species. Some prominent species are listed in Table 2. A particularly rapid spread has been documented for Ips amitinus; about $500 \mathrm{~km}$ in 40 years. A rapid spread has also been observed for Lipoptena cervi, but here the flies may have been carried by their hosts, the elks. Jansson (1991) reported a dispersal of some 10 $\mathrm{km} /$ year for Urophora cardui in southern Finland, which is about four times that reported by Eber \& Brandl (1994) from Central Europe, but as the latter spread is supposed to be a fluctuation, the situations may not be equivalent.

Most of the new species have entered Finland in the south. One prominent exception is the click-beetle Ctenicera cuprea. It was widely distributed in northern Russia, including Russian Karelia, and was first discovered in Finland in Kuusamo. During this century it has spread south and west from there (Fig. 1), lately even reaching Sweden (Lundberg 1991).

The most attention is given to those range extensions that include new country records. Most borders are, however, man-made, and reflect rarely fundamental biological differences. Many species have expanded or diminished their range within Finland during this century. One such species is the leaf beetle Chrysolina sanguinolenta (Linnaeus), which during the last decades has spread west from south-eastern Finland (Silfverberg 1983).

An expansion ends sooner or later, and is often followed by a decline, when much of the new territory is lost; Warren (1992) has described such a fluctuation for Polygonia c-album (Linnacus) in Britain. Kaisila (1962) described the Finnish expansion of Maniola jurtina (Linnaeus), and soon thereafter that species went into a decline, slowly disappearing from almost all of Finland (Järventausta 1987). Now it seems to be returning again. The dragonfly Libellula depressa also disappeared from a large part of the area it had colonized during the early 20th century (Hämäläinen \& Valtonen 1986), and seems now to be returning (Valtonen 1995).

It is difficult to see any reason why the ranges of some particular insect species have expanded, and for others, seemingly similar, they have not. Therefore we can only expect to be surprised again and again. Some species are at present expanding in areas near Finland, and their expansion may continue. For example, among Coleoptera Isorhipis marmottani (Bonvouloir) (Eucnemidae) and Tritoma subbasalis (Reitter) (Erotylidae) have expanded recently in the Baltic area (Roosileht 1994 \& Öunap 1993); in Hymenoptera the bumble bee Bombus schrencki Morawitz has shown a similar expansion (Krzysztofiak 1992 \& Paikans 1990). In future years they may at least be worth looking for.

\section{References}

Biström, O. 1984: Amara hyperborea (Coleoptera, Carabidae), a recent immigrant to Finland? - Notulae Entomol. 64:191-193.

Biström, O. \& Väisänen, R. 1985: Expansion of Agapanthia villosoviridescens to Finland (Coleoptera, Cerambycidae). - Notulae Entomol. 65:156-157.

Clayhills, T. 1991: New provincial records: Gabrius astutoides (Strand). - Entomol. Fenn. 2:5.

Eber, S. \& Brandl, R. 1994: Ecological and genetic spatial patterns of Urophora cardui (Diptera: Tephritidae) as evidence for population structure and biogeographical processes. - J. Anim. Ecol. 63:187-199.

Hackman, W. 1968: Rhamphomyia (Pararhamphomyia) marginata Fabricius funnen i Finland. - Notulae Entomol. 48:90.

Hackman, W., Rantanen, T. \& Vuojolahti, P. 1983: Immigration of Lipoptena cervi (Diptera, Hippoboscidae) in Finland, with notes on its biology and medical significance. - Notulae Entomol. 63:53-59.

Holmberg, H. 1990: Hippodamia notata (Laicharting) Ilomantsista (Coccinellidae), - Notulae Entomol. 69:213.

Hämäläinen, M. \& Valtonen, P. 1986: Suomen sudenkorentojen makkuntaluettelo. - Notulae Entomol. 66:89-90.

Jalas, I. 1992: Perhostenkeräilijän opas (3rd ed.). - Otava, 
Helsinki, 1-272.

Jansson, A. 199l: Distribution and dispersal of Urophora cardui (Diptera, Tephritidae) in Finland in 1985-1991. - Entomol. Fennica 2:211-216.

Järventausta, K. 1987: Varsinais-Suomen suurperhosten levinneisyyskartoitus. - Baptria 」2:33-35.

Kaisila, J. 1962: Immigration und Expansion der Lepidopteren in Finnland in den Jahren 1869-1960. - Acta Entomol. Fenn. 18:1-452.

Kangas, E. 1967: Identification of the Coleoptera collected by the Finnish Spitsbergen expeditions. - Ann. Entomol. Fenn. 33:41-43.

Koponen, M. 1975: Distribution of Ips amitinus Eichh. (Coleoptera, Scolytidae) in Finland in 1950-73. Ann. Entomol. Fenn. 41:65-69.

- 1980: Distribution of Ips amitinus (Eichhoff) (Coleoptera, Scolytidae) in Finland in 1974-1979. - Notulae Entomol. 60:223-225.

Koponen, S. \& Ilvessalo, I. 1986: Runsas Metoecus paradoxus (L.) (Rhipiphoridae) - esiintymä ampiaisen ullakkopesässä Raisiossa. - Notulae Entomol. 66:186-187.

Krzysztofiak, A. 1992: Bombus schrencki Mor. (Apoidea, Hymenoptera) w Polsca. - Przegl. Zool. 36:157-159.

Lindberg, H. 1950: Om några hemipterer, som under senaste tid invandrat till Finland. - Notulae Entomol. 30:49-54.

Lindroth, C. H. 1972: Changes in the Fennoscandian Ground-beetle fauna (Coleoptera, Carabidae) during the twentieth century. - Ann. Zool. Fenn. 9:49-64.

Lundberg, S. 1991: Catalogus Coleopterorum Sueciae 1986-tillägg 2. - Entomol. Tidskr. 112:33-37.

Marttila, O., Haahtela, T, Aarnio, H. \& Ojalainen, P. 1990: Suomen päiväperhoset. — Kirjayhtymä, Helsinki, 362 pp.

Mikkola, K. \& Jalas, J. 1977: Suomen perhoset. Yökköset 1. - Otava, Helsinki, $256 \mathrm{pp}$.

Mikkola, K., Jalas, J. \& Peltonen, O. 1989: Suomen perhoset. Mittarit 2. - Suomen Perhostutkijain Seura, Helsinki, 280 pp.

Nordström, F., Kaaber, S., Opheim, M. \& Sotavalta, O. 1969: De fennoskandiska och danska nattflynas utbredning (Noctuidae). - Lund, CWK Gleerup, 157 pp.

Ólafsson, E. 1991: Islenskt skordýratal. — Fjölrit Náttúrufr, 17:1-69.

Paikans, M. 1990: Jaunas zinas par Latvijas bisu (Hymenoptera, Apoidea) faunu un ekologiju. - Latvijas Entomologs 33:21-26.
Pekkarinen, A., Teräs, I., Viramo, J. \& Paatela, J. 198I: Distribution of bumblebees (Hymenoptera, Apidae: Bombus and Psithyrus) in eastern Fennoscandia. Notulate Entomol. 61:71-89.

Rassi, P. (ed.) 1992: Uhanalaisten eläinten ja kasvien seurantatoimikunnan mietintö. Betänkande av kommissionen för övervakning av hotade djur och växter. Komiteanmietintö. Kommittébetänkande 1991(30): 1328.

Repo, S. 1990: Makrotiedonannot 1989. - Baptria 15:5965.

- 1994: Makrotiedonannot 1993، - Baptria 19:11-16.

Roosileht, U. 1994: The primeval forest of Kanakiula (Estonia) is rich in rare insects. - Salhlbergia 1:15-20.

Rutanen, I. 1992: Rare or interesting beetles (Coleoptera) from Leivonmäki (Sa) and Savonranta (Sb), central Finland. - Entomol. Fenn. 3:4.

- 1994: Etelä-Suomen vanhojen metsien kovakuoriaiset I. - Vesi- ja ympäristöhall. julk. (A) 175:1-80.

Saalas, U. 1923: Studien über die Elateriden Finnlands. 1. Corymbites cupreus Fabr. subsp. aeruginosus Fabr. und seine Verheerungen, besonders in der Gegend von Kainuu. - Anı. Soc. Zool. Bot. Fenn. Vanamo 2:121168.

Silfverberg, H. 1983: The expansion of Chrysolina sanguinolenta and the disappearance of C. gypsophilae in Finland (Coleoptera, Chrysomelidae). - Notulae Entomol. 63:103-105.

- 1990: Nyheter i vår insektfauna. - Finlands Natur 49(5):8-12.

- 1991: Changes 1986-1990 in the list of Finnish insects. - Entomol. Fenn. 2:9-17.

Valle, K. J. 1946: Zur Invasion von Libellula depressa L. (Odon., Libellulidae) nach Finnland. - Ann. Entomol. Fenn. 12:45

Valtonen, P. 1995: Litteähukankorennon (Libellula depressa) uusekspansio Suomessa. - Diamina 4:4-11.

Viramo, J. 1964: Über den Nashornskäfer, Oryctes nasicornis L. (Col., Scarabaeidae), und dessen Verbreitung in Finnland. - Ann. Entomol. Fenn. 30:177187.

Warren, M. S. 1992: The conservation of British butterflies, - In Dennis, R. L. H. (ed.): The Ecology of Butterflies in Britain, Oxford Univ. Press, 246-274.

Öunap, H. 1993: Täienduseks "Fennoskandia, Taani ja Baltikumi mardikaliste nimestikule". - Lepidopterol. Inform. 8:53-55. 